\title{
SUSTAINABLE MANAGEMENT OF WETLANDS: A CASE STUDY OF THE SONGOR RAMSAR AND UNESCO MAN AND BIOSPHERE RESERVE IN GHANA
}

\author{
FIANKO J.R. ${ }^{1}$, DODD H.S. ${ }^{2}$ \\ ${ }^{1}$ Department of Nuclear Sciences and Application, School of Nuclear and Allied Sciences \\ College of Basic and Applied Sciences, University of Ghana Legon, Ghana \\ ${ }^{2}$ Natural Resource Department, Environmental Protection Agency, Accra, Ghana
}

\begin{abstract}
This study on the Songor Ramsar and UNESCO Man and Biosphere Reserve in Ghana seeks to ascertain management method to promote sustainable management of wetlands. The findings clearly indicated that good management practices are employed in the management of the Songor Ramsar Site. The current approaches to management have focused on the harmonious fusion of modern scientific strategies and cultural and traditional methods. In the Songor Ramsar and UNESCO Man and Biosphere Reserve, traditional authorities have enacted traditional rites such as sacred groves and totems in the Ada East District which are strictly enforced to provide traditional regulatory support for their protection while modern conservation approaches in the Songor Wetland management utilizes all the laws in legal protected areas in Ghana. Management also embark on training programmes for users of the wetland resources in sustainable resource utilization to improve economic livelihood. Increased public education and sensitization on the economic importance of the Ramsar Site and the negative impact of environmental degradation has been part of the management strategies. The Public education is on environmentally sound management of waste within the Ramsar Site since the underlying causes of environmental degradation in the Songor Ramsar Site are mainly improper waste disposal, poor attitude of residents toward environmental conservation, wildfires and shoreline recession, inadequate public education on the impact of environmental degradation, fishing, and farming activities. The other factors identified include overgrazing, over exploitation of mangroves, predation, poaching and over fishing, and uncontrolled sand and salt winning.
\end{abstract}

Keywords: Ramsar site, Wetland, Management, Pollution, Lagoon, Songor, Ghana

\section{INTRODUCTION}

In order to achieve development, environmental protection should constitute an integral part of the development process and cannot be considered in isolation (Koukal et al. 2004). In Ghana, awareness of environmental problems is rapidly increasing. In recent years, a growing number of studies stressed the critical situation of several Ghanaian Wetlands (Fianko et al., 2009; WRC 2003). Until recently, wetlands were virtually considered as "waste lands" or areas that only served as breeding grounds for dangerous aquatic reptiles and insects. Since 1988, Ghana has been a signatory to the Ramsar Convention, an international treaty focusing on the conservation of wetlands of international importance. A major obligation

Correspondence Author: Fianko J.R., Dept. of Nuclear

Sciences \& Application, University of Ghana Legon

Email: jrfianko@yahoo.com; fiankojr@gmail.com under the convention is the implementation of the principle of 'wise use' which seeks to address sustainable utilization and management of Ramsar Sites (Ramsar Convention, 1971), including the Songor Ramsar and UNESCO Man and Biosphere Reserve.

The Songor wetland at Ada is one of the five coastal wetlands in Ghana that have been designated as a Ramsar Site under the International Ramsar Convention on Wetlands. It was recently enlisted as Man and Biosphere Reserve of international importance by UNESCO (AfriMAB, 2013). The Songor Ramsar and Biosphere Reserve act as a habitat and breeding ground for several notable species of both economic and ecological importance. It provides multifunctional benefits relating to the ecosystem, the economy, and scenic quality. These benefits include nutrient recycling in bio-ecological adjustment processes, biodiversity conservation, flood conveyance 
and water storage, water purification, groundwater recharge, leisure, and recreation (WRC, 2003).

The Songor Ramsar and Biosphere Reserve is facing many challenges which are mainly anthropogenic even though there are institutions and regulations that manage wetlands. The main challenges induced by human activities in Songor Ramser and UNESCO Man and Biosphere Reserve are pollution, habitat modification, agriculture, proliferation of invasive weeds, predation poaching of turtle and their eggs, waste management especially plastics and unsustainable resource utilization. Changing land use pattern, disposal of liquid effluent and sludge spreading in the wetlands are relatively widespread. Coastal erosion also threatens the shoreline stability with an increasing trend due to climate change while water pollution and hydrological regulation becomes the major threats to the sustainable use of products harvested from the wetlands. The aquatic ecosystem is the ultimate repository of human waste as this technique appears to be cheaper. Concerns have been raised in recent times by cross-section of the Ghanaian public about the preservation of the integrity of the Songor Ramsar site due to inadequate management practices at the wetland and the level of degradation due to anthropogenic activities.

The effective management of coastal wetlands requires the development of technical information based on the status of the biotic components, knowledge and socioeconomic situation of the people in the catchment of the wetland. The management strategy to ensure sustainability of the Songor Ramsar and UNESCO Man and Biosphere Reserve involves multiple use approach aimed at preserving the ecological integrity of the wetland while enhancing its socioeconomic value. To ensure sustainability of the wetland, it is necessary that an assessment of the current management practices are carried out to identify management challenges in the current management practices and proposed mitigation measures to ensure sustainable management of wetlands.

The study is to ascertain the perception and knowledge of communities within the
Songor Ramsar and UNESCO Man and biosphere Reserve catchment of the economic importance of the Ramsar Site. It further determines the factors that contribute to the degradation of the Songor Ramsar and UNESCO Man and Biosphere Reserve and assess the extent to which the current management method promotes sustainable management of the wetland. The study seeks to explore the various ways by which the Songor Ramsar and UNESCO Man and Biosphere Reserve in Ghana could be managed to maintain and preserve the ecological integrity of the ecosystem so as to ensure sustainability of the biological, aesthetic, and production values that the wetlands represents.

\section{METHODOLOGY}

\section{Study area}

The Songor Ramsar Site is located in the Dangbe East District of the Greater Accra Region of Ghana between Latitudes $06^{\circ} 00^{\mathrm{ee}} 25^{\mathrm{ec}} \mathrm{N}-05^{\mathrm{o}} 45^{\mathrm{ec}} 30^{\mathrm{ec}} \mathrm{N}$ and $00^{\circ} 19^{\mathrm{ec}} \mathrm{E}$ $00^{\circ} 41^{\text {ee }} 40^{\text {ee }} \mathrm{E}$ (Figure 1). As one of Ghana's coastal wetlands it falls on the boundary of two flyways of water birds, the East Atlantic Flyway and the Mediterranean Flyway It is $75 \mathrm{~m}$ above sea level in the north, and $15 \mathrm{~m}$ near the Gulf of Guinea (Ramsar Wetlands Information Sheet, 1998). The study area comprises extensive mudflats and low lands covered with reeds and Sesuvium portulacostrum, a broad sandy beach in the south and flood plains with degraded mangroves and coastal savannah vegetation to the east and north. It is important for migratory birds' and other animal species listed in the IUCN Red Data List (Armah, et al., 1998) and has the highest total tern count on the Ghana coast naturally important bird populations (over $10 \%$ of the total coastal count) of at least 23 species of water birds (Pierson et al., 1995). The study area falls within two distinct climatic zones; the dry equatorial climate of the south-east coastal plains and the wet semi-equatorial climate further north from the coast with an average rainfall of $750 \mathrm{~mm}$, humidity $60 \%$ high, and temperature ranging between $23-28{ }^{\circ} \mathrm{C}$ (Benneh \& Dickson, 1998). 


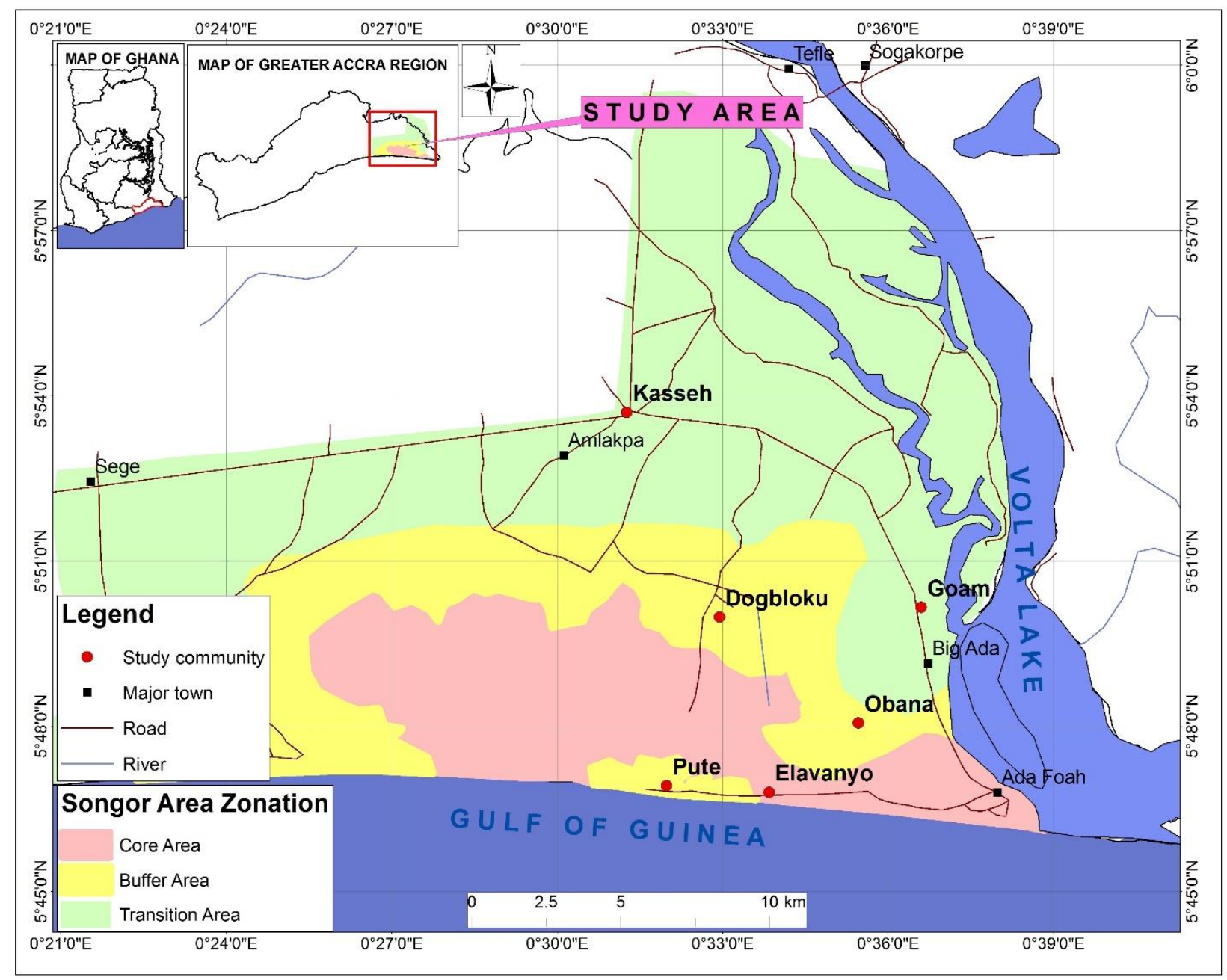

Figure 1. Map of the study area.

\section{Selection of Sampling sites}

The Songor Ramsar Site have been demarcated into three ecological zones (buffer, core, and transitional). Sampling sites were selected to cover all the three ecological zones within the Ramsar Site (Obane, Togbloku, Pute, Elavanyo, Kase, and Gorm). These were major communities within the Ramsar Site where main human activities such as salt mining, fishing, farming, and tourism. The choice of sampling sites depended on the location of the community within the three zones and bulk of human activities within the wetland. Obane and Togbloku are in the Buffer Zone which is located in the northern sector of the open lagoon and is surrounded by floodplain and coastal lands. It is an ecosystem suitable for the breeding of birds, nesting turtles, and a vital coastline for fish breeding and fishing. The buffer zone is characterised by farming, controlled salt mining, tourism and, aquaculture.

The major communities in the Core Zone are Pute and Elavanyo. This zone is located in the south and regarded as the most important feeding and roosting sites for water birds as well as nesting sites for marine turtles and fish species. It has two ecosystem types, marine and brackish (lagoon) which is the aggregation point and core area for birds. The ecosystem diversity of the area is ecotourism, and Sacred Grooves. In the Transition Zone, Kase, and Gorm are in the major communities. This area is mainly composed of settlements with a thin coastal stretch on both ends. This area is fast developing and the current land uses include aquaculture, markets, schools, mechanized shops, and tourism. The ecosystem diversity of this area falls completely within the coastal zone and can be considered as a marine reserve. 


\section{Sampling sites}

Multiple-stage sampling technique was used for the study and these were simple random and purposive sampling. The sampling technique employed was to ensure easy access to specific sections of the population and give equal opportunity for households to be selected. The target population was households from the six selected communities who were randomly selected using the lottery method and 20 key institutions involved in the management of the wetland in the Ada East District. A total of 80 households were randomly selected by virtue of their living in any of the three ecological zones of the Ramsar Site [Buffer Zone - Obane and Togbloku (salt mining, fishing); Core Zone Pute and Elavanyo (fishing, tourism, turtles, sacred groves) and Transitional Zone - Gorm and Kase (trading, farming, settlements)]. Twenty five household were each selected from the core and transition zones whiles 30 households were selected from the buffer zone all based on livelihood and socioeconomic standing of the household. This was done by given households numbers written on pieces of paper, folded and shuffled very well in a container. If the household number was picked then that household was earmarked for the study and provided with a questionnaire to answer. Officers from key institutions involved in the management of the wetland in the Ada East District Assembly were purposively selected.

\section{Data collection}

Both quantitative and qualitative data were collected. Quantitative data were collected through the administration of structured questionnaire using the drop-and-collect approach. Qualitative data were collected through focus group discussion with respondents and key stakeholders in the management of the Ramsar Site. Interviews session were also held for purposively selected key stakeholders in the district. Through the interviews, information such as; the current state of the Ramsar Site, the underlying causes of environmental degradation in the Songor Ramsar site, the governance structure, role played by various stakeholders in management of the wetland and the current methods used in management were sought. An observation schedule was used to guide the researcher to observe incidences such as degradation of the wetland, poaching, predation, habitat modification, and salt winning. To ensure validity and reliability of the instruments, there was pre-testing of the questionnaire and interviews.

\section{Data analysis}

The data collected were statistically analysed using the Statistical Package for Social Studies (SPSS) Software (version 20.0). Responses in the questionnaire collected from the respondents were coded and scored. The data were subjected to descriptive analysis where frequencies and cross-tabulation analysis were employed and processed into statistical tables and figures for easy interpretation and discussion

\section{RESULTS AND DISCUSSIONS}

Sustainable development seeks to address and promote the sustainable utilization of natural resources including wetlands. It is therefore necessary for countries to involve the major stakeholders who live in the catchment of wetland in the decision making process and management (AfriMAB, 2013). Good management practices necessitate the analysis of the perception and knowledge of communities within the Songor Ramsar and UNESCO Man and Biosphere Reserve catchment of the economic importance of the Ramsar Site.

The ages of respondent from households in all the zones ranged from 16-5 years with $49 \%$ of them in the youthful age bracket 31-45 years and $46 \%$ have at least a junior high school education level. The study area is cosmopolitan comprising of a heterogeneous population in terms of tribes, socioeconomic status, level of education, and occupation. Though the Songor wetlands provide multifunctional benefits relating to the ecosystem, the economy and scenic quality, majority of the inhabitants in the catchment were not aware of the socio economic importance of the Ramsar Site. Only $18 \%$ of the communities were aware of the economic importance of the Ramsar Site to the community and the nation as a whole. They 
were of the view that the inhabitants derives benefits (fish, crustaceans such as crabs, lobsters and shrimps, salt and arable land) from the Songor Ramsar Site, and emphatic that the Ramsar Site provide them their source of employment and food as well as promoting tourism and research. Farming, salt winning, fishing, and trading are the major occupation in the study area.

The combination of wetland functions, products and attributes provides benefits important to society. The relative importance of these values and benefits varies among sites due both to the biophysical features of the wetland and the lifestyles of the people. These benefits include biodiversity conservation, flood protection and water storage, water purification, groundwater recharge, leisure and recreation (WRC, 2003). The ranking of natural resources and occupation of the respondents were found to be based on the demarcated zone within which the respondent lives. Fishing is the dominant occupation in the core zone of the Ramsar Site where the major natural resources are lagoons and the sea. Farming, tourism, and trading activities dominate the transitional zone while the buffer zone; salt winning is the dominant occupation. The diversity of habitats in Songor Ramsar Site is important for other ecological functions associated with the wetland. One such function, biogeochemical cycling, involves the biologic, physical, and chemical transformations of various nutrients within the biota, soils, water, and air. Wetlands are very important in this regard, particularly relating to $\mathrm{N}, \mathrm{P}$, and $\mathrm{S}$ (Gibbs, 2000).

The Songor Ramsar Site falls completely within the coastal zone and can be considered as a marine reserve with numerous economic benefits but despite these benefits, extensive magnitude of the resources have been lost due to both natural and anthropogenic activities. The researcher sought to find out the causes of environmental degradation in the wetland. All the respondents were therefore asked to identify the factors that contribute problem of degradation of the Ramsar Site. Many reasons have been assigned to the current state of the Ramsar Site and these include habitat modification for agriculture, proliferation of invasive weeds, predation on turtle eggs by dogs, poaching, infrastructural development, industrial and recreational expansions, pollution, waste dumping and port constructions etc. (Ghana National MAB Committee, 2009). The following indicators of degradation were identified in the Songor Ramsar Site: changes in natural varieties and quantities of vegetation; emergence of weeds particularly invasive ones; poor drainage and reduced flow of water bodies, siltation as well as poor water quality; Changes in biodiversity (species abundance) and changes in the land use patterns as well as soil erosion especially along the coast.

Five main factors were identified by respondents to be contributing to the degradation of the Songor Ramsar Site Improper waste disposal in the communities were considered by $83 \%$ of the respondents as the main factor contributing to the degradation, while $80 \%$ believed poor attitude of residents toward environmental conservation was a key factor. Wildfires and shoreline recession as well as small scale industries, fishing, and farming activities were considered by $78 \%$ of the respondents to be the prime impact and $70 \%$ considered that lack of public education on the impact of environmental degradation on Ramsar Sites is the key cause of environmental degradation in the Songor Ramsar Site. The other factors in order of seriousness include overgrazing and over exploitation of mangroves; predation, poaching and over fishing; uncontrolled sand and salt winning. Poaching and predation of marine turtles and their eggs were identified as a major drawback to tourism development in the wetland. The sand winning has led to the intrusion of seawater into the few fresh water bodies in the communities and serious erosion that has affected houses within the communities.

The analysis revealed a clear relationship between human density, wetland density and wetland degradation. As human settlement pattern shifted from rural to urban, wetland mosaic in the study area shifted from consisting of many clustered wetlands to fewer isolated wetlands which is an indication of degradation (Wilan and Bates, 1995). In poor neighbourhoods, residents only had access to an erratic communal skip services, frequently located at great distances from some residential 
units. Moreover, many peripheral and rural communities in the Songor Ramsar Site had no services, compelling households to dump their waste indiscriminately in any available space. Lack of garbage bins induces people to litter the town and throw their garbage anywhere for convenience. At Kase, located in the Transitional Zone where there is a major market in the District, litter bins had been placed at vehicular terminals to receive waste from the public. Majority of these central bins, however, were uncovered and open which attracts flies, insects and pests posing a human health risk.

During field investigations, it was observed that majority of docks and bins were overflowing wastes are managed by indiscriminate burning in the district. This has the tendency of breeding diseases such as typhoid, cholera, chicken pox which are sanitation related and they pose a serious health threat to the communities. Burning may causes heavy metals like lead, toxic gases and smoke to spread over residential areas. Air pollution due to burning of waste and spreading of toxic fumes may causes large number of damage to both the environment and human health (Medina, 2002). This result confirmed the wellestablished research findings that the underlying causes of environmental degradation of wetlands are mainly a combination of institutional, market, and policy failures (WRC,
2007; Lambin et al., 2003; USGS, 2002; Wang et al., 2001). The impact of solid waste on wetland environment ranges from the release of harmful greenhouse gases to contamination of ground water (Lambin et al., 2003; Gibbs, 2000).

The general principle of good intent and wetland protection is to ensure conservation and wise use of all wetlands through local, regional and national actions and international cooperation, as a contribution towards achieving sustainable development throughout the world (AfriMAB, (2013). Wise use of wetlands is the maintenance of their ecological character, achieved through the implementation of ecosystem approaches, within the context of sustainable development. Wetlands are dynamic areas, open to influence from natural and human factors. In order to maintain their biological diversity and productivity and to allow wise use of their resources by human beings, some kind of agreement is needed between the various owners, occupiers and interested parties. During the focus group discussion and the interviews, all the key stakeholders in wetland management in Ghana asserted that the Songor Ramsar and UNESCO Man and Biosphere Reserve is governed by conventions, bye laws (Figure 2), official patrols and traditional authorities (Amlalo et al., 1998).

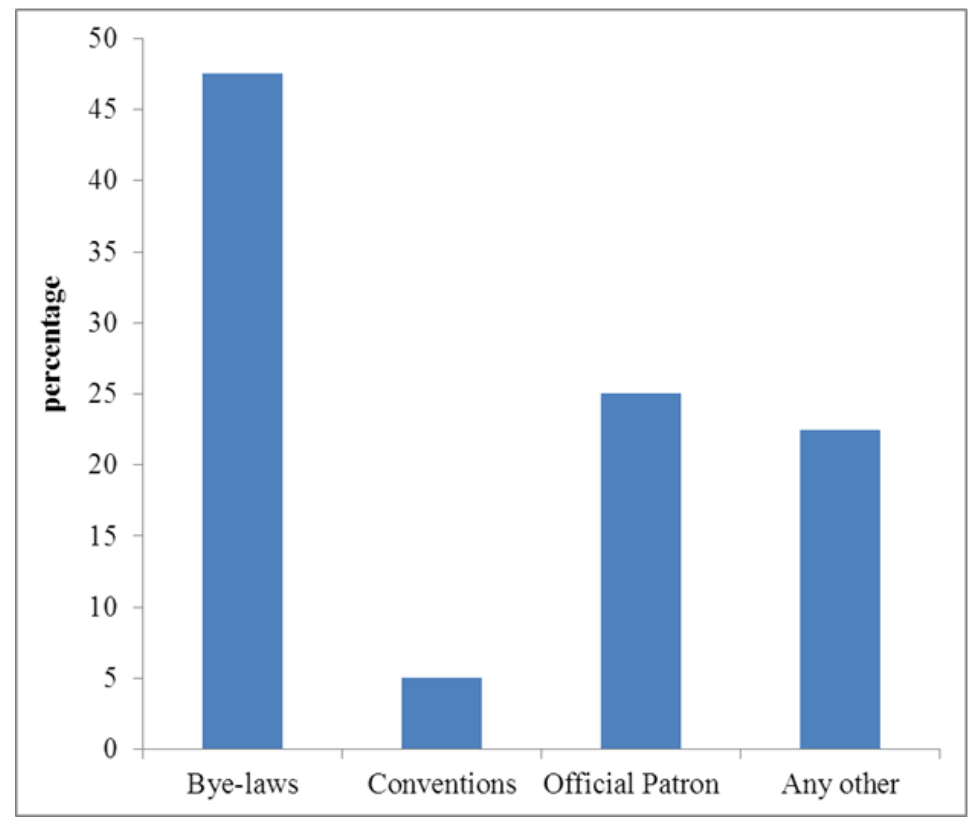

Figure 2. Regulations governing the Songor Ramsar site. 
According to the bye-laws, anthropogenic activities in selected reserved areas in the wetland (poaching, sand wining and game) are illegal while salt wining, settlements and crop farming are restricted to specific areas. The Wildlife Division of the Forestry Commission is the main body in charge of management of the wetland but traditional authorities, District Assembly and opinion leaders in the communities plays significant role. According to the study, the traditional authorities have enacted traditional rites in the District which are strictly enforced. The marine turtle which is totemic to five clans provide traditional regulatory support for their protection (Amlalo et al., 1998). Sacred groves and indigenous beliefs of the natives collectively help to increase the tourist potential of the area. It was revealed in the study that the existing regulation and laws are sufficient enough to ensure sustainability of the wetland. Many factors were identified as the major constrain to the implementation of regulations and laws with respect to conservation and protection of the wetlands. The main weaknesses identified are lack of public education on the economic importance and the need to conserve the wetland, encroachment by developers, lack of enforcement of bye-laws, over-exploitation of mangroves and waste management.

The study revealed that methods such as open burning and dumping of waste among others are unhealthy and are associated with social, ecological, political and economic problems. These findings are consistent with other studies (Yankson, 1998; Schertenleib, and Meyer, 1996) which confirmed that uncontrolled dumping of waste and open burning as a means of waste disposal are common and pose adverse impacts on the surrounding environment.

Managing wetlands effectively requires an understanding of basic ecosystem processes, animal and plant life history strategies, and principles of wildlife management. The cooperative efforts of various stakeholders in formulation, implementation and monitoring successful policies in the sustainable management and conservation of marine resources have been identified to promote good local eco-governance (Gray et al., 2013). According to the major stakeholders in the management of the Songor wetlands, they are implementing biodiversity conservation programmes through sound environmental practices and sustainable resource utilization in the wetland. The Wildlife Division of the Forestry Commission of Ghana was found to be the body in charge of management of the wetland while the traditional authorities plays significant role. The current approaches to management have focused on the harmonious fusion of modern scientific strategies and cultural and traditional methods.

According to management, cultural and traditional conservation methods are still relevant since they cover the broadest range of society and are particularly useful at places where majority of the population lack formal education. In the Songor Ramsar and UNESCO Man and Biosphere Reserve, traditional authorities have enacted traditional rites such as sacred groves and totems in the District which are strictly enforced. This approach is consistent with other studies (Decher, 1997; Ntiamoah Baidu, 1995). The marine turtle is totemic to five clans, providing traditional regulatory support for their protection (Amlalo et al., 1998; Allen, 2002). Sacred groves and indigenous beliefs of the natives collectively help to increase the tourist potential of the area. The sacred groves serve as important ecological and socio-cultural functions by preserving virgin forests, being important refuge for rare and useful local biodiversity and being sources of herbs for medicinal, social and religious purposes (Decher, 1997).

The capacities of traditional authorities and community based organizations have also been strengthened through the transfer of skills and technology to enhance indigenous knowledge. The process of community organizing and building capacity enhances the success of an effective protection and efficient management of Wetlands. Effective collaboration with major stakeholders and increase in public education and sensitization on the economic importance of the Ramsar site and the negative impact of environmental degradation of wetlands are key to sustainable management of wetlands. 
Modern conservation approaches in the Songor Wetland management utilizes all the laws in legal protected areas in Ghana, notably forest reserves, wildlife conservation areas and Ramsar sites. In Ghana there are six Ramsar sites under the management of the Wildlife Division of the Forestry Commission. Such large scale protected areas are critical to the protection of many wildlife species and management of biodiversity. According to Ntiamoah Baidu (1995), the proper coordination and synchronization of activities of various stakeholders can be translated into practical management plans for sustainable wetland resource conservation. Management also embark on training programmes for users of the wetland resources in sustainable resource utilization to improve economic livelihood. Alternative livelihood programmes have been introduced to reduce pressure on the already stressed wetland resources.

\section{CONCLUSION}

Studies on sustainable management of wetlands in Songor Ramsar Site in Ghana clearly indicated that good management practices are employed in the management of the Songor Ramsar Site. The current approaches to management have focused on the harmonious fusion of modern scientific strategies and cultural and traditional methods. In the Songor Ramsar and UNESCO Man and Biosphere Reserve, traditional authorities have enacted traditional rites such as sacred groves and totems in the district which are strictly enforced to provide traditional regulatory support for their protection while modern conservation approaches in the Songor Wetland management utilizes all the laws in legal protected areas in Ghana. Management also embark on training programmes for users of the wetland resources in sustainable resource utilization to improve economic livelihood. Alternative livelihood programmes have been introduced to reduce pressure on the already stressed wetland resources. Increased public education and sensitization on the economic importance of the Ramsar site and the negative impact of environmental degradation has been part of the management strategies. The public education is on environmentally sound management of waste within the Ramsar Site since the underlying causes of environmental degradation in the Songor Ramsar Site are mainly a combination of several factors such as improper waste disposal, poor attitude of residents toward environmental conservation, wildfires and shoreline recession, inadequate public education on the impact of environmental degradation, fishing, and farming activities. The other factors identified include overgrazing, over exploitation of mangroves, predation, poaching and over fishing, uncontrolled sand and salt winning.

\section{REFERENCES}

AfriMAB. 2013. Biosphere Reserves in SubSaharan Africa: Showcasing Sustainable Development. pp 125-139.

Allen GM. 2002. The role of totems in the bushmeat extinction preservation campaign in Ghana. Conservation, Ghana, 2002.

Amlalo DS, Atsiatorme LD, Fiati C. 1997. Biodiversity Conservation, Traditional Knowledge and Modern Concepts. Proceedings of the Third UNESCO MAB Regional Seminal on Biosphere Reserves for Biodiversity Conservation and Sustainable Development in Anglophone Africa (BRAAF) Cape-Coast, 9-12 March 1997, EPA. 2(48): 80-81.

Armah AK, Amlalo DS. 1998. Coastal Zone Profile of Ghana Gulf of Guinea Large Marine Ecosystem Project. Ministry of Environment, Science, Technology and Innovation, Accra, Ghana, pp 10-16.

Benneh G, Dickson KB. 1998. A New Geography of Ghana. Longman Group UK Limited. Longman House Burnt Mill, Harlow, Essex, England. pp. 27-52.

Cunningham WP, Saigo BW. 2001. Environmental Science: A Global Concern. $6^{\text {th }}$ Ed. Boston: McGraw Hill

Decher J. 1997. Conservation, small mammals and the future of sacred groves in West Africa. Biodover. Conserve. 6: 1007-1026.

Fianko JR, Osae S, Achel DG. 2009. The impact of anthropogenic activities on the 
Densu River in Ghana. Water and Environment Journal. 23: 229-234.

Gray MJ, Heath M, Hagy J, Andrew N, Joshua DS. 2013. Management of Wetlands for Wildlife. 3: 121-180.

Gibbs, James P. 2000. Weland loss and biodiversity conservation. Conservation Biology, 14(1): 314-317.

Koukal B, Dominik J, Vignati D, Arpagaus P, Santiago S, Ouddane B, Benaabidate L. 2004. Assessment of water quality and toxicity of polluted rivers Fez and Sebou in the region of $\mathrm{Fez}$ (Morocco). Environ. pollu. 131: 163-172.

Lambin EF, Geist HJ, Lepers E, 2003. Dynamics of land use and land cover change in Tropical regions. Annual Review of Environmental Resources 28: 205-241.

Medina M. 2002. Globalization, development and municipal solid waste management in a third World cities el colegio de la frontera norte (College of the Northern Border),Tijuana Mexico.

Ntiamoah-Baidu Y. 1995. Indigenous versus introduced biodiversity conservation strategies: the case of protected area systems in Ghana. Biodiversity system programs (issues in African biodiversity, No. 1), Washington DC.

Pierson T, Ntiamoah Baidu Y. 1995. Water bird Ecology and the Management of Coastal Wetlands in Ghana. Ghana Coastal Wetlands Management Project. Netherlands Institute for Sea Research (NIOZ) Ghana Wildlife Society Report No.6.

Ramsar Convention. 1971. Convention on wetlands, 1971. Iran.
Ramsar Convention. 1996. Strategic plan $1997-$ 2002. Ramsar Convention Bureau, Gland, Switzerland.

Ramsar Convention. 1998. Monitoring conservation values of a Ramsar wetland vase-wonnerup wetland system. Convention on Wetlands (Ramsar, Iran, 1971), 1998.

Schertenleib R, Meyer W. 1996. Municipal Solid Waste Management in Developing Countries: Problems and Issues; Need for Future research. International Reference Centre for Waste Disposal WHO collaborating Centre. Duebendorf, Switzerland: pp. 2-8.

USGS. 2002. United States Geological Survey: Wetlands and water quality change detection in San Fransis der vco Bay Ecosystem using remotely sensed images. Retrieved, $8^{\text {th }}$ March, 2015.

Water Resources Commission. WRC. 2007. Integrated Water Resources Management Plan - Densu River Basin, WRC, 2007, Accra.

Wang L, Lyons J, Kanehl P, 2001. Impacts of urbanisation on stream habitat and fish across multiple spatial scales. Environmental Management. 28: 255-266.

Wilan BO, Bates MK. 1995. The US fish and wildlife service's. National Wetland inventory project. Vegetation 118: 153-169

Yankson PWK. 1998. The Urban Informal Economy Accommodation, Growth, Linkages, Health and Environmental Impact. The Case of Greater Accra Metropolitan Area (GAMA). Ghana: University Press, Accra. p.36 